\title{
REACH MATHEMATICAL CONNECTION ABILITY BY PROBLEM POSING APPROACH
}

\author{
Nurlissolihah $^{1}$, Indri Lastriyani ${ }^{2}$, Rosalina Rolina ${ }^{3}$ \\ ${ }^{1,3}$ IKIP Siliwangi, Cimahi \\ ${ }^{2}$ STKIP PGRI, Sukabumi \\ ${ }^{1}$ nurlis.guruhebat@gmail.com,${ }^{2}$ Indie1506@gmail.com, ${ }^{3}$ maezarou@gmail.com
}

Received: Sep 12 ${ }^{\text {th }}, 2018 ;$ Accepted: Sep $14^{\text {th }}, 2018$

\begin{abstract}
This study aims to examine the mathematical connection ability of students between the learning using problem posing and the scientific approach. The method used in this study is an experimental method with a pretest-posttest control group design involving two groups and random sampling is taken at the beginning, at the beginning and end of learning the two classes are given a test. The population in this study were junior high school students in Bandung, while the sample consisted of two classes chosen randomly. One class is givenlearning problem posing and the other class is given a scientific approach. The instrument used is a set of 5 test questions describing mathematical connection ability, then the score data is analyzed with descriptive and inferential statistics using SPSS Statistics 21. Based on the results of the study, it was concluded that the achievementabilities of students' mathematical connectionbetween learning using problem posing was better than students who used a scientific approach.
\end{abstract}

Keywords: mathematical connection, problem posing, scientific

\begin{abstract}
Abstrak
Penelitian ini bertujuan untuk menelaah kemampuan koneksi matematik siswa antara yang pembelajarannya menggunakan problem posing dan pendekatan saintifik. Metode yang digunakan dalam penelitian ini adalah metode eksperimen dengan disain kelompok kontrol pretes-postes yang melibatkan dua kelompok dan pengambilan sampel dilakukan secara acak kelas, pada awal dan akhir pembelajaran kedua kelas diberi tes. Populasi dalam penelitian ini adalah siswa SMP di Bandung, sedangkan sampelnya terdiri dari dua kelas yang dipilih secara acak. Satu kelas diberikan pembelajaran dengan problem posing dan kelas lain diberi pendekatan saintifik. Instrumen yang digunakan adalah satu set bentuk tes uraian kemampuan koneksi matematik sebanyak 5 soal, kemudian data skor dianalisis dengan statistik deskriptif dan inferensial menggunakan bantuan SPSS Statistics 21. Berdasarkan hasil penelitian, disimpulkan bahwa pencapaian kemampuan koneksi matematik siswa antara yang pembelajarannya menggunakan problem posing lebih baik dari siswa yang menggunakan pendekatan saintifik.
\end{abstract}

Kata Kunci: koneksi matematik, problem posing, saintifik

How to Cite: Nurlissolihah., Lastriyani, I., \& Rolina, R. (2018). Reach Mathematical Connection Ability By Problem Posing Approach. JIML, 1 (3), 244-247.

\section{INTRODUCTION}

Mathematics learning requires active interaction between educators and students, with the aim that students can receive knowledge, master knowledge, have skills and skills. One of the goals of mathematics education according to Minister of National Education Regulation No. 22 of 2006 is to explain the relationship between concepts and apply concepts or algorithms, flexibly, accurately, efficiently, and precisely, in solving problems and having an attitude of 
respecting the usefulness of mathematics in life, namely having curiosity, attention, and interest in learning mathematics, and tenacity and confidence in problem solving. Students are expected to be able to associate mathematics with other sciences as well as in everyday life, so that mathematics learning will be more meaningful. Therefore, according to Merdian, A., Sari, V. T. A. dan Sugandi, A. I. (2018) the importance of the role of mathematics subjects, students should be able to follow the process of learning mathematics well so that it is easy to accept mathematics learning.

The ability of mathematical connections is the ability of students to find and use interrelationships between topics to solve problems in mathematics, other subjects or in everyday life. NCTM (2000) argues that mathematical connections are one of the five standards of basic mathematical abilities that students must have from elementary to secondary level. This mathematical connection aims to help the formation of students by seeing mathematics as an integrated part of the real world and recognizing the relevance and benefits of mathematics both inside and outside of school. dividing connections into two general types, namely: modeling connection and mathematical connection. Modeling connection is a relationship between problem situations that arise in the real world or in other disciplines with mathematical representations, while mathematical connection is the relationship between two equivalent representations and between the completion processes of each representation. Hendriana, H., Ujang, R.S., Sumarmo (2014) revealed that mathematical connections help students in creating mathematical models that illustrate the relationships of concepts, data, and situations.Wahyudin (2012) presents three indicators developed in mathematical connections, namely:

1. Recognizing and using relationships between mathematical ideas;

2. Understand how mathematical ideas are interconnected and base on one another to produce coherent wholeness;

3. Recognize and apply mathematics in contexts outside mathematics;

Furthermore, Sumarmo (2012) describes several indicators of mathematical connection capabilities including: (1) understanding the relationship between various representations of mathematical concepts and procedures; (2) looking for relationships between various representations of concepts, processes, or mathematical procedures; (3) Understanding between mathematical topics; (4) applying mathematics in other fields or in everyday life; (5) looking for the relationship of one other procedure in an equivalent representation; (6) applying relationships between mathematical topics and between mathematics topics and topics outside mathematics.

Problem posing or problem submission is a form of approach in mathematics learning that emphasizes the formulation of problems or problems. This approach is an alternative learning that can develop mathematical abilities. The problem posing approach is a learning approach by means of the teacher presenting a series of questions that are problematic submission, question submission, question formation, construction of questions and questions generated by students. Silver, E.A., Cai (1996) argue that the term problem posing is used to refer to two senses, namely: 1) developing new problems and 2) reformulating the problems given.

Based on the understanding stated above, it is concluded that what is meant by problem posing is the submission of a problem or formulating a question about a given situation or task, either before, during or after solving the problem. The term "formulating a problem can also be interpreted as" formulating a question ". The term I use is more in reference to the term used in Curriculum and Evaluation Standards for School Mathematics which states "Investigation and formulating questions from problem situations" NCTM (2000).

\section{METHOD}


246 Nurlissolihah, Lastriyani \& Rolina, Reach Mathematical Connection Ability by Problem Posing Approach

This research method is an experimental study with pretest-posttest control group design, namely the design of pretest-posttest control groups involving two groups and randomly taking samples. The research design is described as follows Ruseffendi (2005):

\section{$\mathrm{O} \times \mathrm{O}$}

Description:

$$
\mathrm{O} \mathrm{O}
$$

$\mathrm{O} \quad$ : Problem pretest $=$ posttest question (mathematical connection ability problem)

$\mathrm{X}$ : Learning withapproach problem posing

---- : Random sampling of the class

The population in this study were junior high school students in Cimahi City whose characteristics had low mathematical connection capabilities. The samples were taken from two classes of twelve class VII randomly according to class.

\section{RESULTS AND DISCUSSION}

\section{Results}

Table 1. Data of Research Results

\begin{tabular}{ccccc}
\hline \multirow{2}{*}{ Types ofTests } & Class & \multicolumn{3}{c}{$\begin{array}{c}\text { Data Research Results } \\
\text { Mathematical Connection }\end{array}$} \\
\cline { 3 - 5 } & & $\mathrm{N}$ & $\begin{array}{c}\text { Averag } \\
\mathrm{e}\end{array}$ & $\begin{array}{c}\text { Simp. } \\
\text { Baku }\end{array}$ \\
\cline { 3 - 5 } & & 30 & 0.69 & 0.17 \\
\multirow{2}{*}{ N-Gain } & Experiment & 30 & 0.56 & 0.16 \\
& Control & 30 & 14.57 & 3.06 \\
& Experiment & 30 & 12.30 & 3.17 \\
\hline
\end{tabular}

Table 1. Describe that the average achievement and increase in connection capability Mathematics in the class that gets learning with problem posing is higher than those who get scientific learning.

Table 2. ANOVA Test for 2 Paths

Tests of Between-Subjects Effects

\begin{tabular}{|c|c|c|c|c|c|c|}
\hline Source & $\begin{array}{l}\text { Type III Sum } \\
\text { of Squares }\end{array}$ & Df & Mean Square & $\mathrm{F}$ & Sig. & $\begin{array}{c}\text { Partial Eta } \\
\text { Squared }\end{array}$ \\
\hline CorrectedModel & $220.717^{\mathrm{a}}$ & 5, & 44.143 & 5.675 & & 000,344 \\
\hline Intercept & 9543.131 & 1, & 9543.131 & 1226.928 & & 000,958 \\
\hline Grade & 91.791 & 1 , & 91.791 & 11.801 & & 001,179 \\
\hline Level & 131.511, & 2 & 65.755 & 8.454 & & 001,238 \\
\hline grade $*$ level & 14,220 & 2 & 7,110 &, 914 & , 407 & , 033 \\
\hline Error & 420,016 & 54 & 7,778 & & & \\
\hline Total & 11468,000 & 60 & & & & \\
\hline Corrected Total & 640,733 & 59 & & & & \\
\hline
\end{tabular}

a. R Squared =, 344 (Adjusted R Squared =, 284)

Table 2. shows the significance value of 0.001 in the class group, while in the level of 0.001 , and on the class and 0.407 level.

\section{Discussion}

Two-way ANOVA test shows that there are differences in the achievement of mathematical connection abilities because of the influence of learning, and the level of students' mathematical abilities. While learning interaction with the level of mathematical ability does 
not give effect or differences in the achievement of students' mathematical connection abilities.

From the results of data processing it can be seen that learning with problem posing influences the students' mathematical connection ability. To achieve the mathematical connection ability is seen based on the learning method that learning that uses learning with problem posing in mathematics learning helps in the achievement of students' mathematical connection abilities. Whereas when viewed based on the level of mathematical ability that there is no significant difference between students' mathematical connection ability at a certain level of mathematical ability.

Brown, S.I., Walter (2005) stated that problem posing in mathematics learning has two cognitive stages, namely accepting and challenging. The receiving phase is an activity where the student accepts the task or problem that has been determined. While the challenging stage is an activity where students challenge assignments. Thus, what is meant by the problem posing approach in this study is an approach that emphasizes the formulation or submission of problems by students of the situation or task available. While the understanding of the problem in this study is a question or question. By creating or constructing problems or problems that can be solved, students always construct new understandings based on available information. The questions raised often trigger the formation of a stronger understanding of a person. Through the problem posing approach students can develop students' mathematical mindset such as logical and critical thinking. Furthermore, the development of problem posing in mathematics will improve problem solving abilities.

To increase the ability of mathematical connection is seen based on the learning method that learning that uses learning with problem posing in mathematics learning helps in improving students' mathematical connection abilities. Whereas when viewed based on the level of mathematical ability that there is no significant difference between students' mathematical connection ability at a certain level of mathematical ability.

\section{CONCLUSION}

Based on the research that has been done about mathematical connection ability using problem posing approach with scientific approach can be concluded that:

1. Achievement of students using problem posing approach through is better than scientific approach. 2. There is no difference in improving students mathematical connection ability using problem posing approach and scientific approach.

\section{REFERENCES}

Brown, S.I., Walter, M. . (2005). The Art of Problem Posing. London: Lawrence Erlbaum Associates. Hendriana, H., Ujang, R.S., Sumarmo, U. (2014). Mathematical Connection Ability and SelfConfidence. International Journal of Education, 8(1).

Merdian, A., Sari, V. T. A. dan Sugandi, A. I. (2018). Analisis Kemampuan Komunikasi Matematis dan Keaktifan Siswa SMA dengan Pendekatan Problem Posing. SOSIOHUMANIORA: Jurnal LP3M - UST Yogyakarta, 4(1), 45-50. https://doi.org/10.30738/sosio.v4i1.2279

NCTM. (2000). Principles and Standards for School Mathematics. USA: NCTM.

Ruseffendi, H. E. T. (2005). Dasar-Dasar Penelitian Pendidikan dan Bidang Non- Eksakta Lainnya. Bandung: Tarsito.

Silver, E.A., Cai, J. (1996). An Analysis of Arithmetic Problem Posing by Middle School Students. Journal of Research Mathematics Education.

Sumarmo, U. (2012). Bahan Ajar Mata Kuliah Proses Berpikir Matematik. Bandung: Program S2 Pendidikan Matematika STKIP Siliwangi.

Wahyudin. (2012). Pembelajaran dan Model-Model Pembelajaran. Bandung. 